\title{
ANALISIS KEEFEKTIFAN IKLAN SEBAGAI STRATEGI KOMUNIKASI PEMASARAN PRODUK JENANG CV. MUBAROOKFOOD CIPTA DELICIA MENGGUNAKAN EPIC MODEL
}

\author{
Rizka Octaviani, Sapja Anantanyu, Hanifah Ihsaniyati
}

Program Studi Agribisnis, Fakultas Pertanian, Universitas Sebelas Maret Surakarta Jalan Ir. Sutami No. 36 A Kentingan Surakarta 57126 Telp./Fax (0271) 637457

E-mail: rizkaoctaviani95@student.uns.ac.id

\begin{abstract}
The purpose of this research is to determine the effectiveness of advertising $C V$. Mubarokfood could be seen from four dimensions EPIC (Empathy, Persuasion, Impact and Communication) and to determine the dimensions of EPIC which most dominan. The data used are primary data and secondary data. The technique of collecting data using questionnaires, interviews, and recording. The basic method is Descriptive-Analytic. Analysis using the EPIC model. A questionnaire was distributed to 100 respondents in the area of Central Stores CV. Mubarookfood and Kudus city. Interviews were conducted with the marketing manager. The results showed that the ads that are presented in the form of print media (Brochure), outdoor media ( $X$ Banner, Billboard, Neonbox, Banner) and electronic media (Radio, Internet). The results of the analysis of the effectiveness of ads based EPIC model shows that the advertising of the $C V$. Mubarokfood seen from the dimensions empathy obtained an average score of 4.596, the dimensions of persuasion have a score of 4.244, the dimensions of impact have a score of 4.605 and dimensions of communication have a score of 4.471. The third dimension is included in the scale of "effective", except the dimensions of persuasion are included in the "quite effective" only. The value of the average score is highest impact dimension of 4.605. Overall advertising CV. Mubarokfood considered "effective" with an average score of 4.479. That is able to inform, persuade and remind the public in Kudus city, as well as stimulate the awareness, interest and action ends on the purchase.
\end{abstract}

Keywords: Empathy, Persuasion, Impact, Communication, Advertising Effectiveness

\begin{abstract}
Abstrak: Penelitian ini bertujuan untuk mengetahui tingkat keefektifan periklanan CV. Mubarokfood Cipta Delicia dilihat dari empat dimensi EPIC (Emphaty, Persuasion, Impact dan Communication) dan untuk mengetahui dimensi EPIC (Emphaty, Persuasion, Impact dan Communication) mana yang paling menentukan keefektifan iklan CV. Mubarokfood Cipta Delicia. Jenis data yang digunakan adalah data primer dan data sekunder. Teknik pengumpulan data menggunakan kuisioner, wawancara, dan pencatatan. Metode dasar penelitian adalah deskriptif-analitik. Analisis menggunakan EPIC Model. Kuisioner disebarkan kepada 100 responden di area Toko Pusat CV. Mubarokfood Cipta Delicia dan di kota Kudus. Wawancara dilakukan dengan manajer pemasaran perusahaan. Hasil penelitian menunjukkan bahwa iklan yang disajikan berupa media cetak (Brosur), media outdoor (X-Banner, Billboard, Neonbox, Spanduk), dan media elektronik (Radio, Internet). Hasil analisis tingkat efektifitas iklan berdasarkan EPIC Model menunjukkan bahwa periklanan CV. Mubarokfood Cipta Delicia dilihat dari dimensi emphaty diperoleh skor rata-rata sebesar 4,596, dimensi persuasion memiliki skor sebesar 4,244, dimensi impact memiliki skor sebesar 4,605 dan dimensi communication memiliki skor sebesar 4,471. Ketiga dimensi dimasukkan dalam skala "efektif", kecuali dimensi persuasion yang termasuk dalam "cukup efektif" saja. Nilai skor rata-rata tertinggi adalah dimensi
\end{abstract}


impact sebesar 4,605. Secara keseluruhan periklanan CV. Mubarokfood Cipta Delicia dianggap "efektif" dengan skor rata-rata sebesar 4,479. Artinya mampu menginformasikan, membujuk dan mengingatkan masyarakat di Kudus, serta menstimuli terjadinya kesadaran (awareness), ketertarikan (interest) dan berakhir pada tindakan pembelian (purchase).

Kata kunci : Emphaty, Persuasion, Impact, Communication, Keefektifan Periklanan

\section{PENDAHULUAN}

Pentingnya tindakan penganekaragaman pangan, ditujukan untuk meningkatkan kedaulatan pangan, kemandirian pangan dan ketahanan pangan Indonesia. Hal ini dukungan oleh pemerintah dalam UU RI pasal 118 tentang penelitian dan pengembangan pangan, pengembangan ini salah satu contohnya dalam UU yang dikeluarkan oleh Badan Pengawas Keuangan dan Pembangunan dalam situsnya bpkp.go.id (2015) adalah merekayasa inovasi teknologi pengembangan produk pangan olahan berbasis pangan lokal, agar memiliki nilai tambah dan daya saing yang tinggi sehingga mampu mewujudkan kemandirian ekonomi masyarakat. Salah satu wilayah di Indonesia yang mengembangkan pangan olahan adalah kota Kudus.

Kota kudus terletak di Jawa Tengah merupakan kota industri. Terdapat beberapa jenis industri: industri olahan tembakau, pabrik gula, industri elektronik dan lain-lainnya. Industri pangan olahan yang sangat familiar di Kudus adalah industri Jenang. Di Kudus sendiri menurut Dinas Perindustrian, Koperasi dan UMKM Kabupaten Kudus (2015) dalam data Direktori Industri Kecil dan Menengah tahun 2014 diketahui bahwa Jumlah UMKM Jenang di Kudus sebanyak 77 unit dengan berbagai macam jumlah kapasitas produksi (ton)/ bulan tiap unitnya.

Banyaknya jumlah industri, serta didukung oleh perkembangan teknologi modern, menuntut pelaku industri Jenang di Kudus tidak hanya bersaing dengan produk perusahaan lain, namun juga merebut hati konsumen di pasaran. Kotler (2008) dalam Setiawan (2011) berpendapat Persaingan antar produk di pasaran mendorong produsen berpromosi untuk menarik perhatian konsumen. Wartiningsih dan Herawati (2005) mengatakan promosi yang dianggap paling efektif adalah iklan. Menurut Nielsen (2000) kampanye iklan memainkan bagian kritis dalam pembangunan atau pembentukan kekuatan merek (brand equity). Sehingga harus dapat dipastikan dengan benar, tercapainya tujuan, dan efektiftitas iklannya agar maksimal serta mampu membangun citra merek.

Oleh karena itu, iklan sangat penting bagi perusahaan produk maupun jasa, tanpa adanya iklan, sebaik dan sehebat apapun produk/ jasa yang dihasilkan, jika tidak di komunikasikan ke masyarakat tentang keberadaannya, maka hal itu akan sia-sia. Begitu pula yang dilakukan oleh CV. Mubarookfood Cipta Delicia menerapkan strategi komunikasi pemasaran dengan kontinyu dan konsisten dalam mengiklankan hasil produknya diberbagai media agar tetap eksis dimata pasar. Menurut hasil survei sementara, jika dilihat segi kreatifitas iklan yang dikeluarkan CV. Mubarookfood Cipta Delicia, periklanan yang dilakukan masih dibilang sederhana, belum menggunakan endorser sebagai penyampai pesan iklan, namun kegiatan ini masih konsisten dilakukan dan tentunya memakan banyak biaya. Contohnya, akan sering dijumpai billboard, spanduk besar terpampang nama dari perusahaan ini di area jalanan kota Kudus bahkan di kota lainnya.

Periklanan memang mahal, kerapkali efeknya tidak pasti dan terkadang membutuhkan waktu sebelum memiliki dampak terhadap perilaku membeli pelanggan (Shimp, 2003). Didukung juga bahwa biaya iklan yang tinggi mampu menumbuhkan volume penjualan (Bram, 2005). Aktifitas periklanan berkorelasi erat dengan biaya, berdasarkan uraian di atas, periklanan memperoleh perhatian yang serius, strategi dan program yang efektif dan efisien diperlukan untuk mencapai dampak iklan yang diinginkan, tidak luput dari itu, juga diperlukan teknik pengukuran untuk memantau keefektifan iklan CV. Mubarokfood Cipta Delicia menggunakan salah satu alat ukur keefektifan iklan yaitu EPIC Model, sehingga dapat diketahui tingkat 
keefektifan iklan CV. Mubarokfood Cipta Delicia dilihat dari empat dimensi EPIC (Emphaty, Persuasion, Impact dan Communication) dan dimensi mana yang dominan mempengaruhi keefektifan iklan yang disajikan.

\section{METODE PENELITIAN}

Metode dasar penelitian yang dilaksanakan dalam kurun waktu kurang lebih satu bulan masa penelitian pada bulan Agustus 2016 menggunakan metode Deskriptif-Analitik (Surakhmad, 1998) dengan teknik penelitian Survei (Ruslan, 2003). Penentuan lokasi penelitian dilakukan secara purposive (sengaja) (Singarimbun dan Effendi, 1989) yaitu di CV. Mubarokfood Cipta Delicia Kudus dengan pertimbangan bahwa sekitar lokasi ini tempat berdirinya perusahaan Jenang CV. Mubarokfood Cipta Delicia, dan menurut Mubarokfood.co.id (2015) perusahaan ini telah lama berdiri lebih dari 1 abad (1910) dimana sudah menggunakan periklanan sebagai strategi komunikasi pemasaran yang modern dan luas dibanding dengan perusahaan sejenis lainnya.

\section{Populasi dan Sampel}

Metode pengambilan sampel pada penelitian ini menggunakan convenient sampling Hasan (2002) dengan pertimbangan kemudahan dengan menggunakan dasar teori milik Gay dan Diehl (1992) dalam Ruslan (2003) yaitu sekurang-kurangnya 100 sampel di sekitar area toko pusat CV. Mubarokfood Cipta Delicia dan masyarakat di wilayah kota Kudus diambil secara purposive yaitu dengan pertimbangan sudah pernah melihat iklan semua atau sebagian yan disajikan CV. Mubarokfood Cipta Delicia.

\section{Data dan Teknik Pengumpulan Data}

Data yang digunakan dalam penelitian ini adalah data primer dan data sekunder. Teknik pengumpulan data yang digunakan dalam penelitian ini adalah kuesioner, pencatatan, dan observasi.

\section{Metode Analisis Data}

Metode analisis data untuk mengukur tingkat keefektifan iklan menggunakan pendekatan EPIC Model yaitu dengan memisahkan empat dimensi (Emphaty, Persuasion, Impact dan
Communication). Menurut Durianto, et al. (2003) dalam Ismail (2008) Tahapannya adalah setiap jawaban dari responden diberi bobot, setelah itu, digunakan skala penilaian untuk menentukan posisi tanggapan responden dengan menggunakan nilai skor. Setiap variabel bobot alternatif jawaban yang terbentuk di peringkat terdiri dari kisaran antara 1 sampai 7 (skala likert) yang menggambarkan posisi yang sangat negatif ke posisi yang positif. Setelah didapat hasil nilai masingmasing dari dimensi EPIC kemudian membuat diagram EPIC.

\section{HASIL DAN PEMBAHASAN}

Jenang adalah panganan tradisional dari Kota Kudus, merupakan salah satu produk UKM yang melesat cepat diantara produk-produk olahan UKM yang lain. Salah satunya adalah CV. Mubarokfood Cipta Delicia yang sudah mengalami turun temurun 3 generasi. Mubarokfood Cipta Delicia adalah produsen Jenang Kudus dengan merek-merek terkenal: Mubarok, Viva, Mabrur, Sinar Tiga Tiga, Jawa Rasa, Baginda, dan Semesta. Selain memproduksi Jenang Kudus, Dodol dengan merek Citra Persada yang diolah dengan menggunakan teknologi vacuum.

Tiap generasi memiliki masa kejayaan dan mencapai perkembangan masing-masing. Mulai generasi ketiga yaitu mulai tahun 1992 UMKM ini mengalami perkembangan yang sangat pesat yaitu dari segi manajemen, fasilitas maupun proses pengolahan produk serta penerapan teknologi. CV. Mubarokfood Cipta Delicia memiliki kapasitas produksi kurang lebih 400 ton/bulan. Perusahaan ini sangat mengedepankan kualitas melalui teknologi terstandar dan terukur sehingga ditujukan untuk semua lapisan menengah ke atas. Namun, meskipun dibawah payung perusahaan yang sama, masing-masing merek memiliki target pasar yang berbeda. Untuk menyesuaikan karakteristik setiap segmen di pasar, maka perusahaan menyediakan produk dengan beraneka merek dagang. Perusahaan dalam menghadapi masalah harga, berusaha memberlakukan penganekaragaman harga karna ingin menyesuaikan karakteristik tiap segemen pasar. Kantor pusat CV. Mubarokfood Cipta Delicia berlokasi di Jalan Sunan Muria No. 33 Gang Kyai Khidzir, Glantengan, Kudus, 
Jawa Tengah dengan No. telp (0291) 432606/ (0291) 423633. Lokasi ini dijadikan tempat produksi sekaligus Toko Pusat penjualan produk. Secara umum, CV. Mubarokfood Cipta Delicia menggunakan berbagai jenis alat promosi dalam mengkomunikasikan produknya yang terdiri dari promosi penjualan (sales promotion), dan pemasaran langsung (direct selling), penjualan pribadi (personal selling), publisitas (public relation) dan periklanan (advertising). Media periklanan yang telah digunakan perusahaan melalui (1. Media Cetak (Brosur/Selebaran); (2. Media Outdoor (Xbanner, Neonbox, Spanduk/ Umbul-umbul, Billboard); (3. Media Elektronik (Internet, Radio).

\section{Karakteristik Responden}

Responden yang berjumlah 100 sebesar $71 \%$ adalah Wanita, karena Wanita memiliki ketertarikan yang tinggi dalam berbelanja, tingkat selektifitas yang tinggi mengenai produk makanan yang sedang nge-trend dan yang memiliki kualitas tinggi di pasaran, serta seringkali mudah menangkap paparan iklan yang disajikan. Usia 21-30 tahun mendominasi yaitu sebesar $58 \%$ dengan pendidikan terakhir mayoritas SMA sebesar 61\%, menjelaskan bahwa skala usia tersebut dapat dikatakan sebagai kategori yang memiliki tingkat tingkat pengetahuan/ wawasan, kesadaran tinggi terhadap aneka paparan iklan yang disajikan. Serta pada usia yang masih tergolong muda tersebut, imajinasi atau kreatifitas mengenai suatu desain visual juga tinggi. Karakteristik responden sebagian besar mengeluarkan anggaran konsumsi $\leq$ Rp. 1.000 .000 dan didukung dengan $65 \%$ masih berstatus pelajar/mahasiswa ini mengartikan bahwa biasanya membeli Jenang untuk oleh-oleh. Meskipun dengan pengeluaran bulanan yang minim, dan juga Jenang termasuk makanan sekunder, sehingga intensitas pembelian tidak sesering seperti pembelian pada makanan primer, sehingga hal ini tidak menghalangi responden untuk tetap membeli Jenang untuk oleh-oleh khas Kudus.

\section{Kefektifan iklan dengan EPIC Model Dimensi Empathy}

Tabel 1. Dimensi Emphaty

\begin{tabular}{lccccccc}
\hline \multirow{2}{*}{ Atribut } & \multirow{2}{*}{$\begin{array}{c}\text { Bobot } \\
\text { (W) }\end{array}$} & \multicolumn{6}{c}{ Frekuensi (F) } \\
\cline { 3 - 8 } & E1 & E2 & E3 & E4 & E5 & E6 \\
\hline $\begin{array}{l}\text { Sangat tidak } \\
\text { setuju sekali }\end{array}$ & 1 & 0 & 1 & 1 & 7 & 2 & 2 \\
Sangat tidak & 2 & 2 & 5 & 1 & 4 & 5 & 5 \\
setuju & 3 & 3 & 5 & 8 & 14 & 24 & 13 \\
Tidak setuju & & & & & & & \\
Cukup setuju & 4 & 20 & 24 & 28 & 29 & 32 & 34 \\
Setuju & 5 & 48 & 39 & 34 & 28 & 20 & 30 \\
Sangat setuju & 6 & 15 & 18 & 20 & 12 & 12 & 10 \\
Sangat setuju & 7 & 12 & 8 & 8 & 6 & 5 & 6 \\
sekali & & & & & & & \\
\hline
\end{tabular}

$$
\begin{aligned}
& \begin{array}{lllllll}
\text { TOTAL } & 100 & 100 & 100 & 100 & 100 & 100
\end{array} \\
& \text { Sumber : Data Primer, } 2016 \\
& \bar{x} \mathrm{E}_{1-6}=\frac{5,070+4,810+4,850+4,270+4,190+4,390}{6} \\
& =\frac{27,58}{6} \\
& =4,5967
\end{aligned}
$$

Hasil analisis tingkat keefektifan iklan produk CV. Mubarokfood Cipta Delicia yang dipasang di berbagai media, diketahui pada indikator kemampuan untuk mengenali iklan dicerminkan dengan pernyataan E1, E2 dan E3 pada kuisioner. Kemampuan yang dimaksud adalah kemampuan responden dalam mengenali/ menyadari ciri khas merek dalam iklan Mubarok yang dipaparkan. Dengan rincian sebanyak 100 responden menyatakan "setuju" bahwa iklan Mubarok mudah dikenali/disadari keberadaannya dengan skor 5,070 pada E1. Hal ini karena Mubarokfood sangat gencar dan konsisten dalam mengiklankan produknya dibanding pesaing.

Penjabaran selanjutnya dilihat dari penilaian terhadap E3 yaitu dari segi warna iklan memperoleh skor 4,850 yang artinya responden juga "setuju" bahwa warna iklan yang disajikan sudah bagus secara visual. Karena warna sangat penting untuk diperhatikan, cara penggabungan dan cara memposisikan warna dalam visual yang tepat, tentu akan menghasilkan persepsi yang tepat pula. Penjabaran lain dari indikator di atas 
selanjutnya, berdasarkan penilaian yang diperoleh untuk E2 diketahui dari segi konten/isi iklan dengan nilai skor 4,810 dinilai "bagus" oleh responden. Konten/isi yang dimuat cukup lengkap pada media Brosur maupun internet yang penjelasannya detail isinya sudah dijabarkan di poin sebelumnya. Konten/isi iklan yang bagus akan mampu meningkatkan product knowledge responden dan mampu menimbulkan daya tarik.

Indikator kedua yaitu cara pandang/ persepsi responden dalam menempatkan iklan kedalam diri responden dimana dicerminkan dengan pernyataan E4 dan E5. Seperti pada pernyataan E4, tagline/slogan yang disajikan oleh Mubarokfood yang sudah dijelaskan pada poin sebelumnya, telah dinilai oleh 100 responden sebesar 4,270 yang artinya responden "cukup setuju" bahwa tagline/slogan tersebut unik bagi pribadi responden. Kemudian penilaian pada E5 terlihat dari 100 pribadi responden setelah terpapar iklan menyatakan bahwa responden "cukup setuju" iklan Mubarok mampu menyenangkan suasana hati responden dengan skor 4,190. Hal ini menginformasikan bahwa iklan Mubarok mampu menimbulkan daya tarik emosional. Indikator terakhir yaitu Responden memberikan skor sebesar 4,390 pada pernyataan ke E6 yang artinya bahwa responden "menyukai" iklan. Hal ini menginformasikan bahwa responden menyukai iklan yang disajikan karena dapat memberikan daya tarik emosional sehingga iklan sesuai dengan yang diinginkan dalam benak responden. Kesukaan responden terhadap iklan dipengaruhi oleh banyak faktor misalnya isi pesan dan jenis media yang divisualisasikan. Berdasarkan hasil perhitungan rata-rata dimensi emphaty yaitu sebesar 4,5967, maka rentang skala keputusan seperti di bawah ini:

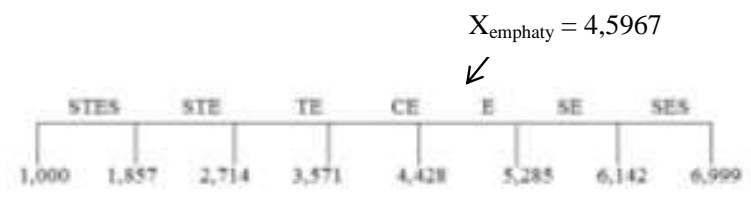

Gambar 1. Rentang Skala Keputusan Dimensi Emphaty (Analisis Data Primer, 2016)

\section{Dimensi Persuasion}

Tabel 2. Dimensi Persuasion

\begin{tabular}{lcccccc}
\hline \multirow{2}{*}{ Atribut } & \multirow{2}{*}{ Bobot } & \multicolumn{5}{c}{ Frekuensi } \\
\cline { 2 - 7 } & & P1 & P2 & P3 & P4 & P5 \\
\hline $\begin{array}{l}\text { Sangat tidak setuju } \\
\text { sekali }\end{array}$ & 3 & 7 & 10 & 2 & 7 \\
Sangat tidak setuju & 2 & 6 & 9 & 7 & 8 & 4 \\
Tidak setuju & 3 & 13 & 24 & 19 & 12 & 14 \\
Cukup setuju & 4 & 27 & 26 & 26 & 29 & 28 \\
Setuju & 5 & 31 & 19 & 18 & 22 & 26 \\
Sangat setuju & 6 & 13 & 11 & 13 & 16 & 13 \\
Sangat setuju sekali & 7 & 7 & 4 & 7 & 11 & 8 \\
\hline Total & & 100 & 100 & 100 & 100 & 100
\end{tabular}

Sumber : Data Primer, 2016

$$
\begin{aligned}
\bar{x} \mathrm{P}_{1-5} & =\frac{4,440+3,900+4,020+4,530+4,330}{5} \\
& =\frac{21,22}{5} \\
& =4,244
\end{aligned}
$$

Hasil analisis tingkat keefektifan iklan, diketahui pada indikator ketertarikan/ termotivasi untuk terlibat dengan merek yang hal ini tercermin pada pernyataan $\mathrm{P} 1, \mathrm{P} 2$, dan P3 dalam kuisioner. Motivasi responden yang dimaksud adalah dorongan dalam diri responden untuk melakukan keterlibatan/ mendapatkan informasi merek dari iklan Mubarok. Seperti data yang diperoleh pada P1, responden mengaku terbujuk dan menjadi "tertarik" dengan produk setelah terpapar iklan sesuai dengan skor sebesar 4,440. Strategi menguatkan karakter merek dalam benak konsumen agar membentuk sikap dan keinginan dapat dipengaruhi, salah satunya dengan konsisten memaparkan informasi iklan yang berulang-ulang.

Penilaian P2 dengan skor sebesar 3,900 yang menerangkan responden merasa "cukup tertarik/termotivasi" untuk tergerak/terdorong untuk mencari-cari iklan di media lain setelah terpapar disalah satu media. Selanjutnya bentuk dorongan berperilaku lainnya tercermin pada P3 yang menyatakan bahwa responden "cukup ingin tahu" dan ingin memahami lebih lanjut tentang seluk beluk produk setelah melihat iklannya berdasar penilaian skor 4,020. Hal ini artinya iklan Mubarok mampu menimbulkan stimulus rasa ingin tahu. 
Dorongan perubahan pada indikator brand trust yang ditimbulkan akibat iklan tercermin pada P4 yaitu responden merasa dengan senang hati dan "percaya" terhadap produk Mubarokfood setelah terpapar iklan dengan skor sebesar 4,530. Hal ini karena iklan yang disajikan sudah mampu menjawab keraguan dalam benak responden. Dilihat dari indikator keinginan untuk mencoba/membeli yang tercermin pada P5 dengan skor 4,330 bahwa dorongan yang ditimbulkan lainnya adalah responden berhasil dibujuk agar memiliki rasa "ingin" membeli setelah terpapar iklan. Ini karena iklan menggunakan bahasa persuasive sehingga mampu membujuk/ mendorong rasa ingin mencoba dan membeli.

Berdasarkan hasil perhitungan rata-rata dimensi persuasion yaitu sebesar 4,244, maka rentang skala keputusan seperti berikut:

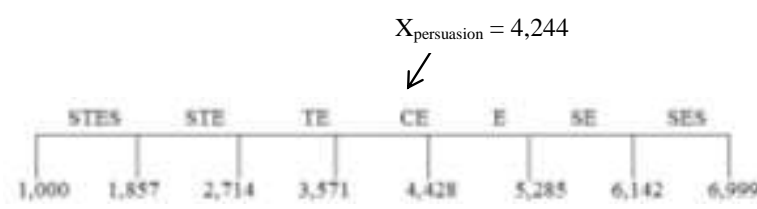

Gambar 2. Rentang Skala Keputusan Dimensi Persuasion

(Analisis Data Primer, 2016)

\section{Dimensi Persuasion}

Tabel 3. Dimensi Impact

\begin{tabular}{|c|c|c|c|c|c|c|c|c|c|}
\hline \multirow{2}{*}{ Atribut } & \multirow{2}{*}{ Bobot - } & \multicolumn{6}{|c|}{ Frekuensi } & \multirow[b]{2}{*}{ I7 } & \multirow[b]{2}{*}{ I8 } \\
\hline & & I1 & $\mathrm{I} 2$ & $\mathrm{I} 3$ & I4 & I5 & I6 & & \\
\hline $\begin{array}{l}\text { Sangat tidak } \\
\text { setuju sekali }\end{array}$ & 1 & 1 & 1 & 1 & 4 & 7 & 1 & 2 & 5 \\
\hline $\begin{array}{l}\text { Sangat tidak } \\
\text { setuju }\end{array}$ & 2 & 2 & 3 & 5 & 14 & 5 & 1 & 7 & 15 \\
\hline Tidak setuju & 3 & 16 & 4 & 12 & 16 & 12 & 13 & 12 & 21 \\
\hline Cukup setuju & 4 & 33 & 14 & 21 & 18 & 17 & 14 & 20 & 19 \\
\hline Setuju & 5 & 32 & 32 & 34 & 32 & 31 & 34 & 32 & 19 \\
\hline Sangat setuju & 6 & 10 & 27 & 17 & 10 & 20 & 25 & 21 & 10 \\
\hline $\begin{array}{l}\text { Sangat setuju } \\
\text { sekali }\end{array}$ & 7 & 6 & 19 & 10 & 6 & 8 & 12 & 6 & 11 \\
\hline Total & & 100 & 100 & 100 & 100 & 100 & 100 & 100 & 100 \\
\hline
\end{tabular}

Sumber : Data Primer, 2016

$\bar{x} \mathrm{I}_{1-8}=\underline{4,470+5,300+4,730+4,140+4,520+}$ $\underline{5,020+4,600+4,060}$

$$
\begin{aligned}
& =\frac{36,84}{8} \\
& =4,605
\end{aligned}
$$

Hasil analisis tingkat keefektifan iklan, diketahui dari indikator penilaian kreatifitas iklan yang tercermin pada I1 dan I2 yang menilai apakah hasil karya Mubarokfood yang dinilai telah berbeda dan menonjol dibanding hasil karya iklan pesaing atau tidak. Diketahui sebanyak 100 responden menyatakan "setuju" bahwa iklan Mubarok merupakan terobosan yang kreatif dengan skor 4,470. Penilaian selanjutnya tercermin pada I2 yang menyatakan bahwa iklan Mubarok "sangat menonjol" dibandingkan dengan iklan pesaing. Hal ini menginformasikan bahwa Mubarok sangat memperhatikan perencanaan iklan dengan baik dan gencar beriklan sehingga iklan Mubarok sangat mudah ditemui di Kota Kudus.

Indikator kedua yaitu mengenai kemampuan product knowledge dicerminkan dari I3, I4 dan I5 hal ini menginformasikan bahwa responden memiliki product knowledge yang luas mengenai pengetahuan tentang ciri/ karakter merek, konsekuensi/manfaat positif penggunaan merek, dan mampu menilai pencapaian suatu produk dalam memuaskan konsumennya. Diperoleh skor 4,470 pada I3 yang artinya responden "mengetahui" dengan baik keunggulan produk Mubarok. Keunggulan yang dimaksud adalah dalam bentuk keunggulan kualitas produk yang melebihi produk pesaing. Kemudian pada I4 didapati skor 4,140 yang artinya responden "cukup mengetahui" dengan baik mengenai varian produk Mubarok setelah melihat iklannya. Serta pada I5 diperoleh skor 4,520 yang artinya responden "mampu" membedakan dengan baik ciri-ciri merek Mubarok dengan merek lainnya. Berdasar peroleh skor tersebut, menginformasikan bahwa iklan yang disajikan Mubarok mampu memberikan informasi yang dibutuhkan responden.

Dimensi impact dalam indikator keterlibatan maksudnya bentuk perwujudan motivasi responden untuk lebih aktif dalam mendekatkan diri responden terhadap produk. Tercermin pada kuisioner pernyataan I6 dan I7. Dimana diperoleh skor 5,020 pada I6 menyatakan "sering" merekomendasikan Mubarok kepada keluarga/ rekan. Ini menunjukkan bahwa produk ini dapat diandalkan dan mampu dipercaya masyarakat luas. Dampak lainnya yang dihasilkan dari indikator tersebut tercermin pada I7 adanya perubahan bentuk perilaku responden yang 
"setuju" akan segera melakukan pembelian nyata setelah terpapar iklan. Buktinya dapat dilihat pada akun media sosial yang tercantum bahwa pada kolom komentar terdapat pertanyaan yang diajukan masyarakat tentang bagaimana cara membeli produk pada salah satu postingan iklan Mubarok di media.

Indikator terakhir adalah brand loyalty maksudnya berupa komitmen dimana responden melakukan pembelian ulang yang konsisten dan sebagai sikap apresiasi positif terhadap merek. Hal ini didukung perolehan skor sebesar 4,060 pada I8 artinya responden "cukup setuju" bahwa tidak akan beralih merek dan akan selalu setia (loyal) pada Mubarok setelah terpapar iklan. Brand loyalty ini adalah suatu bentuk hasil dari brand trust yang terdapat pada dimensi persuasi. Berdasarkan hasil perhitungan rata-rata dimensi impact yaitu sebesar 4,605, maka rentang skala seperti berikut:

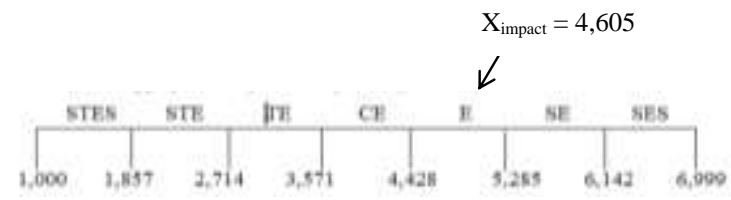

Gambar 3. Rentang Skala Keputusan Dimensi Impact (Analisis Data Primer, 2016)

\section{Dimensi Communication}

Tabel 4. Dimensi Communication

\begin{tabular}{lccccccc}
\hline \multirow{2}{*}{ Atribut } & \multirow{2}{*}{ Bobot } & \multicolumn{7}{c}{ Frekuensi } \\
\cline { 3 - 8 } & & C1 & C2 & C3 & C4 & C5 & C6 \\
\hline $\begin{array}{l}\text { Sangat tidak } \\
\text { setuju sekali }\end{array}$ & 1 & 3 & 1 & 9 & 1 & 9 & 5 \\
$\begin{array}{l}\text { Sangat tidak } \\
\text { setuju }\end{array}$ & 2 & 9 & 2 & 8 & 1 & 13 & 4 \\
Tidak setuju & 3 & 6 & 3 & 20 & 8 & 18 & 20 \\
Cukup setuju & 4 & 15 & 29 & 17 & 30 & 20 & 26 \\
Setuju & 5 & 37 & 32 & 20 & 32 & 27 & 30 \\
Sangat setuju & 6 & 18 & 22 & 17 & 22 & 8 & 10 \\
Sangat setuju & 7 & 12 & 11 & 9 & 6 & 5 & 5 \\
sekali & & 100 & 100 & 100 & 100 & 100 & 100 \\
\hline Total & & & & & & & \\
\hline
\end{tabular}

Sumber : Data Primer, 2016

$\bar{x} \mathrm{C}_{1-6}=\underline{4,760+4,990+4,180+4,810+3,870+}$ $\underline{4,220}$

$$
\begin{aligned}
& =\frac{26,83}{6} \\
& =4,471
\end{aligned}
$$

Hasil analisis tingkat keefektifan iklan, diketahui pada indikator tingkat kejelasan informasi iklan dibandingkan iklan pesaing dicerminkan melalui kuisioner pada $\mathrm{C} 1, \mathrm{C} 2$ dan C3. Dengan rincian sebanyak 100 responden menilai pada C1 "setuju" bahwa cara iklan Mubarok lebih jelas dibanding iklan pesaing skor sebesar 4,760. Selanjutnya penilaian responden pada C2 yang mendapat skor 4,990 yang artinya responden "setuju" bahwa iklan Mubarok sudah menggunakan bahasa yang baik dan benar. Serta pada C3 diketahui skor sebesar 4,180 yang artinya responden "cukup setuju" bahwa slogan/ tagline yang dipaparkan pada iklannya cukup jelas. Sehingga hal ini memudahkan responden memahami dengan baik maksud kata dalam iklan. Didukung oleh penilaian dari indikator tingkat pemahaman responden terhadap iklan dicerminkan pada $\mathrm{C} 4$ yang memperoleh skor sebesar 4,810 yang artinya responden "memahami" dengan baik maksud kata dalam iklan.

Indikator tingkat kemampuan responden dalam mengingat pesan iklan tercermin pada C5 yang memperoleh skor sebesar 3,870 yang artinya responden "cukup mampu mengingat" pesan yang dipaparkan. Serta pada indicator tingkat kekuatan kesan yang ditinggalkan oleh iklan dalam benak responden yang tercermin pada C6 memiliki skor sebesar 4,220 yang artinya responden "cukup mampu" menangkap kesan yang diberikan oleh iklan Mubarok. Hal ini menginformasikan bahwa iklan Mubarok cukup mampu memberikan pesan utama dan kesan yang cukup kuat dalam benak responden. Berdasarkan hasil perhitungan skor rata-rata dimensi communication yaitu sebesar 4,471, maka rentang skalanya seperti berikut:

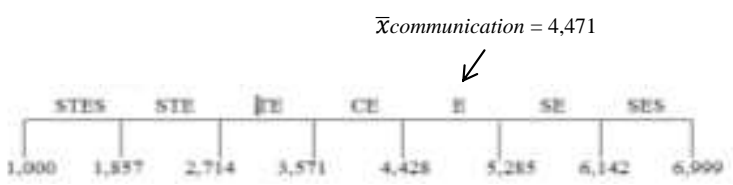

Gambar 4. Rentang Skala Keputusan Dimensi Communication

(Analisis Data Primer, 2016) 
EPIC Rate

$$
\begin{aligned}
\bar{x} \text { epic }= & \underline{\underline{x}}_{\underline{E}}+\bar{x}_{\underline{P}}+\bar{x}_{\underline{I}}+\bar{x}_{\mathrm{C}} \\
& =\frac{4,596+4,244+4,605+4,471}{4} \\
& =\frac{1792}{4} \\
& =4,479
\end{aligned}
$$

Berdasarkan hasil perhitungan di atas perhitungan EPIC Rate iklan Mubarokfood diperoleh sebesar 4,479 yang artinya bahwa iklan ini "efektif" artinya (Shimp, 2003) mampu menginformasikan, membujuk dan mengingatkan masyarakat Kudus tentang produk hasil CV. Mubarokfood Cipta Delicia serta (Kotler, 2003) menstimuli terjadinya kesadaran (awareness), ketertarikan (interest) dan berakhir pada tindakan pembelian (purchase) yang dilakukan oleh responden terhadap produk CV. Mubarokfood Cipta Delicia. Durianto et.al., (2003) dalam Ninong (2005) Suatu iklan dikatakan efektif, jika mampu membangun kesadaran pada suatu merek dibenak konsumen dan dampak yang ditimbulkan dari iklan berpengaruh terhadap keputusan pembelian. Dalam kriteria pengingatan, yang umum dipakai sebagai ukuran adalah kemampuan konsumen dalam mengingat iklan atau bagian dari iklan tersebut. Kemudian hal apa sajakah yang mereka tangkap dari iklan yang ditayangkan. Konsep ini menjadi penting untuk iklan yang ditujukan untuk memperkuat kesadaran akan merek (brand awareness). Selain itu, iklan yang efektif, dapat diketahui melalui riset tentang dampak penjualan yang disebabkan dari iklan yang disampaikan dan juga pemahaman konsumen terhadap suatu iklan, terhadap perubahan kepercayaan konsumen pada ciri atau konsekuensi produk, sikap terhadap merek, keinginan membeli. Apakah suatu iklan dapat menciptakan rantai akhir suatu pengetahuan produk (knowledge product) sebagaimana yang diinginkan, yaitu menemukan apakah konsumen membentuk pengasosian yang tepat antara merek dengan pribadi konsumen. Hasil dari penelitian ini sudah mampu memenuhi tujuan-tujuan dari masing-masing dimensi.

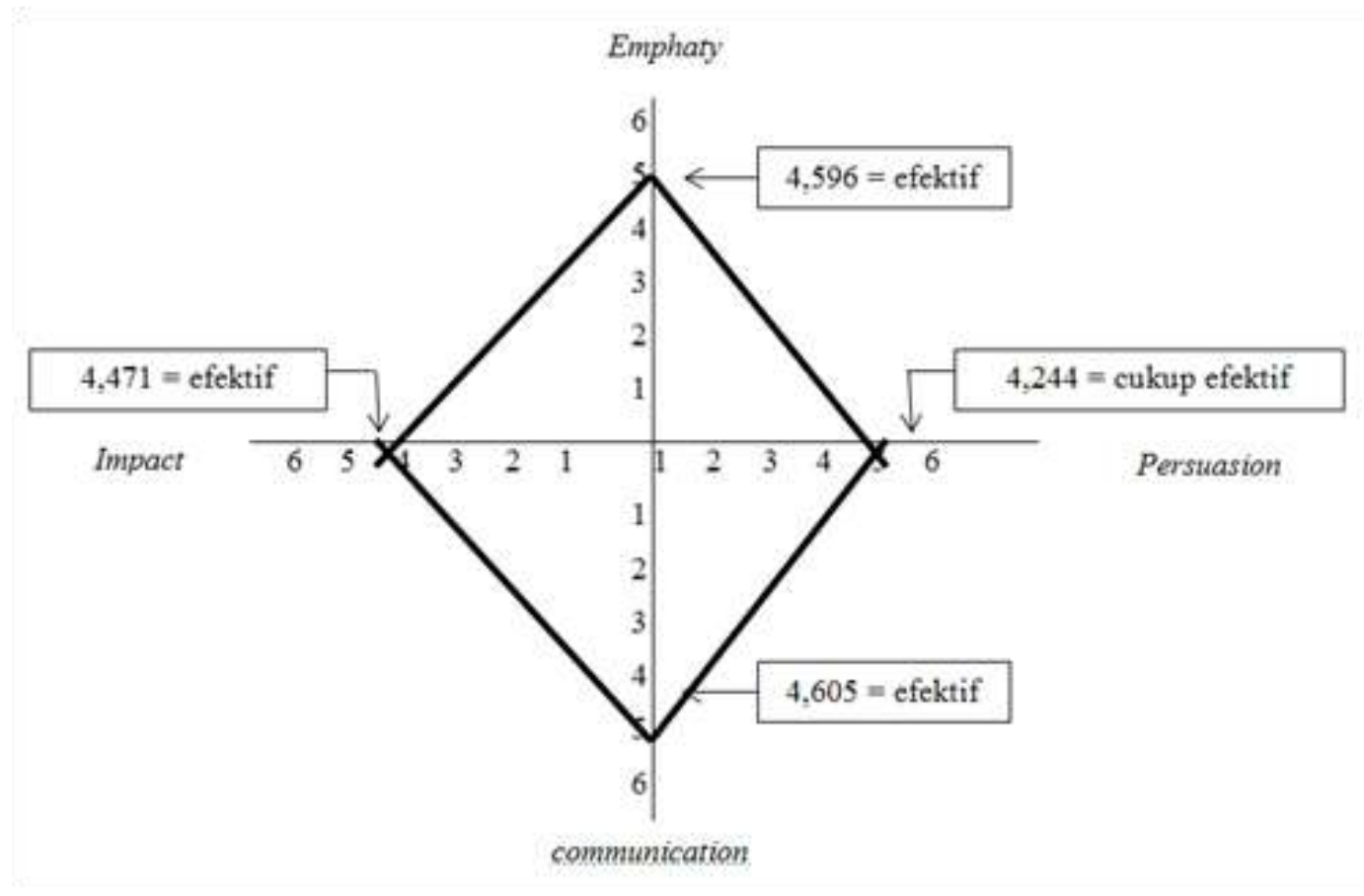

Gambar 5. Diagram EPIC iklan CV. Mubarokfood Cipta

Delicia (Analisis Data Primer, 2016) 


\section{KESIMPULAN DAN SARAN}

\section{Kesimpulan}

Kegiatan iklan yang dilakukan CV. Mubarokfood Cipta Delicia meliputi periklanan melalui media cetak (Brosur), media outdoor (x-banner, billboard, neonbox, Spanduk/ umbul-umbul), dan media elektronik (Radio, Internet). Hasil analisis tingkat keefektifan iklan CV. Mubarokfood Cipta Delicia berdasarkan EPIC Model menunjukkan bahwa iklan sudah "efektif" artinya mampu menginformasikan, membujuk dan mengingatkan masyarakat Kudus tentang produk dan menstimuli terjadinya kesadaran (awareness), ketertarikan (interest) dan berakhir pada tindakan pembelian (purchase) yang dilakukan oleh responden terhadap produk CV. Mubarokfood Cipta Delicia dengan EPIC Rate sebesar 4,479. Dimensi emphaty diperoleh skor rata-rata sebesar 4,596, dimensi persuasion sebesar 4,244, dimensi impact sebesar 4,605 dan dimensi communication sebesar 4,471. Ketiga dimensi dimasukkan dalam skala "efektif", kecuali dimensi persuasion yang termasuk dalam "cukup efektif" saja.

Kegiatan iklan yang dilakukan CV. Mubarokfood Cipta Delicia dari skor rata-rata keempat dimensi memiliki skor rata-rata tertinggi pada dimensi $\bar{x}$ impact sebesar 4,605 menurut perhitungan skala masuk pada skala "efektif". Hal ini menjelaskan bahwa dimensi ini yang paling menentukan keefektifan iklan CV. Mubarokfood Cipta Delicia dibanding dimensi lain. Dari dimensi ini menginformasikan bahwa Mubarokfood sangat memperhatikan perencanaan iklan dengan baik dan gencar beriklan sehingga iklan Mubarok dinilai kreatif dan menonjol karena sangat mudah ditemui di Kota Kudus. Selain itu dampak yang terjadi adalah responden mengaku memiliki product knowledge yang luas mengenai pengetahuan tentang ciri/ karakter merek, konsekuensi/manfaat positif penggunaan merek, dan mampu menilai pencapaian suatu produk dalam memuaskan konsumennya. Selain itu, responden juga terjadi perubahan lebih aktif dalam mendekatkan diri terhadap produk seperti merekomendasikan produk ke keluarga/ kerabat dan segera melakukan pembelian nyata setelah terpapar iklan. Dalam bentuk loyalitas, dimensi ini mampu membuat komitmen responden dalam melakukan pembelian ulang yang konsisten dan sebagai sikap apresiasi positif terhadap merek.

\section{Saran}

Berdasarkan hasil penelitian, saran yang dapat diberikan sebagai berikut: 1) Dalam rangka meningkatkan keefektifan dimensi persuasion, jika selama ini belum ada endorser sebagai penyampai iklan, cara lain adalah dengan menyewa endorser yaitu dengan cara membuat kontrak agar produk diiklankan oleh Artis atau tokoh yang berpengaruh lainnya melalui aplikasi Instagram atau media lainnya. Biasanya akan lebih sedikit memakan biaya, karena hanya cukup mengirimkan produk ke calon endorser tersebut, namun hal ini tergantung isi dari perjanjian kontrak iklan tersebut; 2) CV. Mubarokfood Cipta Delicia agar terus mempertahankan kinerja iklan yang sudah dijalankan karena persaingan Agroindustri sejenis pasti akan semakin berkembang. Salah satu caranya adalah dengan merencanakan iklan lebih baik, lebih imajinatif, dan lebih menghibur konsumen. Strategi kreatif akan memainkan peran yang semakin penting dalam kesuksesan suatu iklan. Dewasa ini, semakin majunya teknologi, iklan Internet sudah mulai banyak digunakan, sehingga saran yang dapat diberikan antara lain: (a) Membuat iklan dalam bentuk Video yang dapat disebarkan melalui Aplikasi Facebook, Twitter, Youtube, Instagram maupun social media lainnya. (b) Membuat iklan di Facebook ads, Twitter ads maupun social media lainnya.

\section{DAFTAR PUSTAKA}

Badan Pengawas Keuangan dan Pembangunan. 2015. UU RI No 18 tahun 2012 tentang Pangan. www.bpkb.go.id. Diakses 25 Maret 2016.

Bram, Yudi Farola. 2005. Analisis Efektivitas Iklan Sebagai Salah Satu Strategi Pemasaran Perusahaan Percetakan Dan Penerbitan PT Rambang Dengan Menggunakan Metode EPIC Model. Jurnal Manajemen \& Bisnis Sriwijaya, 3(6):1-23. 
Dinas Perindustrian, Koperasi dan UMKM Kab. Kudus. 2015. Direktori Industri Kecil dan Menengah 2014. Kudus.

Hasan, M. Iqbal. 2002. Pokok-Pokok Materi Metodologi Penelitian Dan Aplikasinya. Bumi Aksara. Jakarta.

Ismail, Mohammad Afiek. 2008. Analisis Efektifitas Iklan Televisi Produk Rokok X-Mild "Ekspresikan Aksimu" Edisi Band Netral dengan Menggunakan EPIC Model. Skripsi. Universitas Islam Negeri (UIN) Malang.

Kotler, Philip. 2003. Manajemen Pemasaran, (Alih Bahasa: Hendra Teguh, Ronny A. Rusli \& Benyamin Molan). Prenhalindo. Jakarta.

Nielsen AC. 2000. EPIC Dimensions Of Advertising Effetiveness. AC Nielsen ads@work brochure.
Ninong, Nindarti. 2005. Pengukuran Efektifitas Iklan Televisi Fren Versi "Kereta Api" dengan EPIC Model. Skripsi. Universitas Brawijaya.

Ruslan, Rosady. 2003. Metode Penelitian: Public Relations Dan Komunikasi. PT. Raja Grafindo Persada. Jakarta.

Setiawan, Nugroho Ardhi. 2011. Analisis Faktor-Faktor Yang Mempengaruhi Efektifitas Ikln Televisi Axis "Penjual Gorengan". Skripsi. Universitas Diponegoro.

Shimp, Terrence. 2003. Periklanan Promosi: Komunikasi Pemasaran Terpadu, Jilid 2 edisi kelima. Erlangga. Jakarta.

Wartiningsih, Endah dan Tuty Herawati. 2005. Pengaruh Iklan Visual Produk Shampoo Di Televisi Terhadap Pemilihan Konsumsi Shampoo. Jurnal Ekonomi dan Bisnis, 4(3):183-198. 